\title{
A blue crab (Callinectes sapidus Rathbun, 1896) individual with partial albino: A case report
}

\section{Kısmi albinolu bir mavi yengeç (Callinectes sapidus Rathbun, 1896) bireyi: Bir vaka raporu}

\author{
Akın Türker İlkyaz ${ }^{1 *} \bullet$ Zafer Tosunoğlu² \\ 1 Department of Fishing Technology, Faculty of Fisheries, Ege University, Izmir, Turkey (iD https://orcid.org/0000-0003-2650-3223 \\ ${ }^{2}$ Department of Fishing Technology, Faculty of Fisheries, Ege University, Izmir, Turkey (iD https://orcid.org/0000-0002-1168-9611 \\ *Corresponding author: ilkyaza@gmail.com
}

Received date: 07.09.2018

Accepted date: 19.10 .2018

How to cite this paper:

İlkyaz, A. T. \& Tosunoğlu, Z. (2019). A blue crab (Callinectes sapidus Rathbun, 1896) individual with partial albino: A case report. Ege Journal of Fisheries and Aquatic Sciences, 36(1), 85-86. DOI: 10.12714/egejfas.2019.36.1.11

Abstract: In this study, a partial albino finding of a blue crab specimen sampled in Köyceğiz Lagoon (Muğla, Turkey) is presented. The carapace part of the individual was in normal colour and pseudo-albinism was observed in most of the extremities of the specimen.

Keywords: Partial albinism, pseudo-albinism, Köyceğiz, Aegean Sea

Öz: Bu çalışmada, Köyceğiz Dalyanı́nda (Muğla, Türkiye) örneklenen bir mavi yengeç bireyinde gözlenen kısmi albinoluk bulguları sunulmuştur. Bireyin karapaks kısmı normal renginde olup bireyin ekstremitelerinin büyük kısmında yalancı-albinoluk gözlemlenmiştir.

Anahtar Kelimeler: Kısmi albinizm, yalancı-albinoluk, Köyceğiz, Ege Denizi

\section{INTRODUCTION}

Natural habitat of blue crab (Callinectes sapidus Rathbun, 1896) is western Atlantic from Nova Scotia (Canada) to Rio de la Plata (Argentina). The species introduced in the eastern Atlantic, North Sea, Mediterranean Sea, Adriatic Sea, Black Sea and IndoPacific (Palomares and Pauly, 2018). In addition to it is an exotic species for Turkey that was first sampled in 1959 (Holthuis, 1961). Blue crab is a benthopelagic and omnivore species, and it can lives both freshwater and brackish. The species lives at depths between 0 and 90 $\mathrm{m}$ however, it usually prefers the depth range from 0 to 35 m (Palomares and Pauly, 2018).

The species is commercial and production takes place in the Aegean Sea and the Mediterranean. According to the last decade years statistics, the annual production quantity is $16.6 \pm 8.0( \pm$ SE) tons (TÜIK, 2009; TÜiK, 2017).

The purpose of this study is to report the partial albino observed in a blue crab. Although such a partial albino cases have been previously reported
(Gowanloch, 1952; Sims and Joyce, 1965; Williams, 1974) such case is reported for the first time from Turkey.

\section{MATERIAL AND METHODS}

The blue crab specimen was sampled on 12 September 2017 by DALKO Lagoon Fishery Cooperative (Köyceğiz, Muğla, Turkey) (3654'58.7"N 28³9'23.9"E). The individual was caught with a crab trap in an area with 2-3 m depth and a sandy and muddy bottom. The sample is fixed in a 4\% formaldehyde solution and stored at the Ege University Fisheries Faculty Museum with ESFM-MAL/2017-9 registration number.

\section{RESULTS AND DISCUSSION}

It was determined that the individual is female, the carapace width of the individual is $201.39 \mathrm{~mm}$ and the total weight is $307.19 \mathrm{~g}$. The morphological characteristics and color pattern is accordance with Williams (1974). 
On the right side of the individual; all parts except dactyl parts of the swimming leg and the tip of the cheliped' fixed finger and dactyl were albino. On the left side of the individual; all of the third leg, the merus part of the first leg, the coxa and propodus parts of the swimming leg, and the dactyl parts of the second and fourth legs were pseudo-albinizm. It was determined that the carapace part of the individual had normal colours (Figure 1).

It is known that the color difference between these individuals is related to the sexual dimorphism and molt cycle (Williams, 1974). However, the situation observed in this individual does not originate from these reasons. The albinism observed in the crabs - partially or wholly white - reported as sporadic (Hogarth, 1982). Similarly, albinism and partial albinism found in blue crab species have previously been reported in scientific literature and these individuals are kept in the museum (Gowanloch, 1952; Sims and Joyce, 1965). General assumption is that albinism seen in crabs is similar to that seen in humans, due to the absence of pigment and is genetically determined (Hogarth, 1982). According to Hogarth (1982), both assumptions are questionable.

In this study, partial albinism findings of a blue crab individual are presented. Since there is no scientific evidence to explain the cause of the partial albinism observed in the individual, it is not known whether this is an individual's pigment deficiency, genetic origin, or both.

\section{ACKNOWLEDGEMENTS}

The present study was sponsored by Ege University Scientific Research Project fund (BAP project no 16-

\section{REFERENCES}

Gowanloch, J.N. (1952). The Louisiana crab fishery. Louisiana Conservationist, 4(9-10), 6-9.

Hogarth, P.J. (1982). "Albinism" in Crabs (Decapoda, Brachyura) Crustaceana, 43(2), 200-201. DOI: 10.1163/156854082X00533

Holthuis L.B. (1961). Report on a collection of Crustacea Decapoda and Stomatopoda from Turkey and the Balkans. Netherlands: Brill.

Palomares, M.L.D., \& Pauly, D. (2018). SeaLifeBase. World Wide Web electronic publication 2018. www.sealifebase.org, version $(02 / 2018)$
SÜF-010). We would like to thank Arif YALILI, who is the chief of DALKO Fisheries Cooperative, for his assistance and its related members.

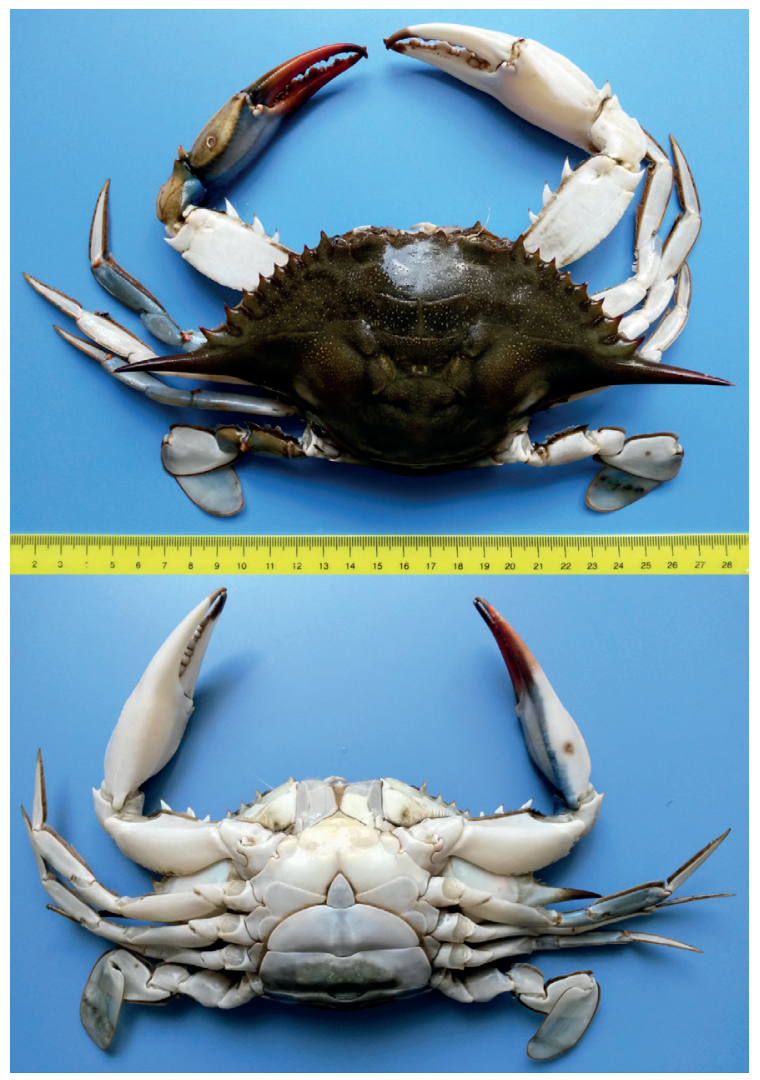

Figure 1. Dorsal and ventral views of the specimen (Photo: A. T. Illkyaz)

Sims, H.W., \& Joyce, E.A. (1965). Partial albinism in a blue crab. Quarterly Journal of the Florida Academy of Sciences, 28, 373-374.

TÜIK (2009). Fisheries Statistic 2008. Turkish Statistical Institute Printing Division, Ankara, Turkey.

TÜIK (2017). Fisheries Statistic 2016. Turkish Statistical Institute, Ankara, Available at http://www.tuik.gov.tr/HbGetir.do?id=27669\&tb_ $\mathrm{id}=3$ (03.08.2018).

Williams, A.B. (1974). The swimming crabs of the genus Callinectes (Decapoda: Portunidae). Fishery Bulletin, 72(3), 685-798. 